\title{
Strategi Komunikasi Pemerintah dalam Mengimplementasikan Program Pol PP Desa di Kabupaten Empat Lawang
}

\author{
Hendra Gunawan $^{1 *}$, Yenrizal ${ }^{1}$, K.A Bukhori ${ }^{1}$ \\ ${ }^{1}$ UIN Raden Fatah Palembang, Indonesia
}

\begin{abstract}
Abstrak: Penelitian ini bertujuan untuk mengetahui strategi komunikasi pemerintah dalam mengimplementasikan program Pol PP Desa di Kabupaten Empat Lawang. Penelitian ini dilakukan menggunakan penelitian deskriptif kualitatif. Penelitian ini menyimpulkan bahwa strategi komunikasi yang dilakukan Pemerintah Empat Lawang untuk mengimplementasikan program Pol PP Desa bahwa program tersebut merupakan rintisan yang pertama di Indonesia. Berupa penempatan petugas Pol PP di setiap desa se kabupaten Empat Lawang diberikan fasilitas pos jaga. Proses berjalannya program tersebut juga dilengkapi dengan aplikasi “SIAP Pol PP Desa" dan dapat dilakukan pengawasan, kontrol, serta perintah atasan jam dan dimana pun juga. Masyarakat/netizen pun dapat dengan mudah memberikan informasi apapun yang terjadi di kabupaten Empat Lawang sesuai dengan petunjuk aplikasi Siap Pol PP Desa tadi. Bahkan didukung penuh oleh Polres Empat Lawang dalam bentuk program Kegiatan Rutin Yang Ditingkatkan (KRYD). Hasilnya implementasi program tersebut salah satu cara komunikasi pemerintah yang sangat efektif, berimplikasi dengan menekan angka kejahatan kriminal di Bumi Saling Keruani Sangi Kerawati.
\end{abstract}

Kata Kunci: komunikasi pemerintah, program Pol PP Desa, strategi komunikasi

\begin{abstract}
This study aims to describe how to build sustainable supervision in the field of education. As for this study, using literature research, so that only looking at reviews based on existing theories. This study concludes that the coaching and professional development of teachers is very important, because it will have an impact on the quality of schools/madrasahs, but it is necessary to pay attention to efforts to develop and develop the competence of educators, which should be followed by the participation of the central and local governments and must be supported by stakeholders like society. In addition, there must be teacher work motivation, implementing open management, implementing job descriptions with clear tasks and functions, implementing vertical downward relationships, mapping programs and activities to increase work motivation, continuous and comprehensive supervision, and evaluation.
\end{abstract}

Keywords: komunikasi pemerintah, program Pol PP Desa, strategi komunikasi

\section{Pendahuluan}

Pembentukan Kabupaten Empat Lawang diresmikan 20 April 2007 lalu, setelah dikeluarkannya Undang-Undang Nomor 1 tahun 2007. Terbentuknya kabupaten Empat Lawang itu sendiri, merupakan salah satu konsekuensi terhadap otonomi daerah sebagaimana yang diatur dalam Undang-Undang Nomor 22 Tahun 1999 tentang Pemerintah Daerah yang kemudian direvisi menjadi Undang-Undang Nomor 32 Tahun 2004.

Fenomena belakangan terakhir kabupaten Empat Lawang lebih dikenal sebagai daerah

\footnotetext{
* Corresponding Author: Hendra Gunawan (gunawanh932@gmail.com). UIN Raden Fatah Palembang, Indonesia
} 
kabupaten yang akrab dengan kejahatan, rawan, kerap terjadi pencurian, begal, dan sebagainya. Hal ini menyusul adanya berbagai kejadian di lingkungan masyarakat Empat Lawang itu sendiri. Mulai dari kejahatan kriminal seperti pencurian, begal bahkan konflik antar masyarakat pada kegiatan tahapan pemilihan kepala daerah, maupun legislatif. Hingga mengakibatkan memakan korban jiwa serta kesenjangan antar kelompok masyarakat terutama para pendukung politik.

Sejurus dengan kejahatan dan konflik tersebut, maka pembangunan kabupaten Empat Lawang sedikit lambat dibandingkan dengan daerah pemekaran lainnya, tercatat dalam data Badan Pusat Statistik (BPS) Kabupaten Empat Lawang pada tahun 2017 sebanyak 244.312 jiwa dan sekitar 30.29 ribu jiwa penduduk tergolong masih miskin. Diyakini persoalan tersebut dipengaruhi karena sebagian penduduk enggan untuk bepergian berkebun bercocok tanam ke lahan pertanian lantaran daerah kabupaten Empat Lawang rawan dengan kejahatan.

Selanjutnya bupati H Joncik Muhammad yang dilantik sejak 18 September 2018 bersama pasangannya $\mathrm{H}$ Yulius Maulana sebagai wakil bupati. Keinginan mereka adalah mewujudkan daerah yang diamanatkan kepada mereka aman dan nyaman. Juga hendak mengubah paradigma masyarakat yang mengecap bahwa kabupaten Empat Lawang adalah daerah yang rawan kejahatan menjadi daerah yang ramah lingkungan. Maka strategi komunikasi yang dilakukan pemerintah Empat Lawang yang menjadi prioritas utama adalah menekan angka kejahatan.

Sebagaimana yang kita ketahui, regulasi hukum Peraturan Pemerintah No. 6 tahun 2010 tentang Satuan Polisi Pamong Praja (Satpol PP). Kemudian direvisi PP No 16 tahun 2018 tentang Satpol PP. Tercantum dalam Pasal 5 bahwasannya
Satpol PP mempunyai tugas: a. menegakkan Perda dan Peraturan Kepala Daerah (Perkada), b. menyelenggarakan ketertiban umum dan ketentraman, c. menyelenggarakan perlindungan masyarakat. Sehingga eksistensi Satpol PP setiap daerah kabupaten/kota ditentukan sesuai dengan kebutuhan masing-masing daerah. Selain PP diatas, dalam melaksanakan tugasnya dilengkapi dengan Permendagri No. 54 tahun 2011 tentang Standar Operasional Prosedur (SOP) Satpol PP.

Selanjutnya pada pasal 2 ayat 1 tersebut, dijelaskan untuk menegakkan Peraturan Daerah, dan menyelenggarakan ketertiban umum dan ketentraman serta menyelenggarakan perlindungan masyarakat di setiap provinsi dan kabupaten/kota dibentuk Satpol PP. Dan pada ayat 2, pembentukan Satpol PP sebagaimana dimaksud pada ayat (1) ditetapkan dengan Perda provinsi dan Perda kabupaten/kota sesuai dengan ketentuan peraturan perundang-undangan. Sehingga pemerintah kabupaten Empat Lawang telah menetapkan keputusan Perda No. 9 tahun 2016 tentang Pembentukan dan Susunan Perangkat Daerah Kabupaten Empat Lawang, yang didalamnya ada bab yang mengatur tentang Organisasi Perangkat Daerah (OPD) Satuan Pol PP Empat Lawang. Lantaran kabupaten Empat Lawang merupakan salah satu daerah yang dinilai rawan kejahatan kriminal, maka pemerintah telah merintis program Pol PP desa sebagai upaya memberikan rasa keamanan dan kenyamanan bagi masyarakat kabupaten Empat Lawang. Dalam melaksanakan operasi program itu, disertai aplikasi SIAP Pol PP Desa yang bertujuan untuk mengontrol dan mengawasi lajunya program Pol PP Desa secara online.

Sejauh ini, didapati beberapa penelitian sebelumnya terkait eksistensi, penugasan Pol PP di sejumlah wilayah Indonesia. Diantaranya penelitian bersama dari Universitas Maritim Raja 
Ali Haji atas nama Jufita Puspa Sari, Rumzi Samin, dan Ramadhani Setiawan. Dengan judul Strategi Satuan Polisi Pamong Praja Dalam Penertiban Pedagang Kaki Lima (PKL) Kota Tanjungpinang (Studi Pada Wilayah Pasar Kelurahan Tanjungpinang Kota). Permasalahan yang diangkat pada penelitian tersebut yakni PKL kerap mengganggu tatanan ruang kota yang diatur oleh pemerintahan setempat dan juga mengganggu hak bagi pejalan kaki. Maka dilakukan penertiban dan pemindahan PKL. Meskipun dikesimpulan bahwa penertiban dan pemindahan PKL tersebut tidak membuahkan hasil. Namun peneliti mengajukan saran kepada pemerintah setempat untuk melakukan penertibaan dan pemindahan lokasi PKL sejatinya harus ada kesiapan lahan dan lokasi yang layak bagi PKL tersebut (Jufita, 2018).

Kemudian penelitian yang kedua dari penelitian bersama atas nama Ibnu Tantowi bersumber dari Universitas 17 Agustus 1945 Samarinda. Dengan judul Implementasi Penataan Pedagang Kaki Lima (PKL) oleh Satuan Polisi Pamong Praja Kota Samarinda. Mereka melakukan penelitian ini bertujuan untuk mengetahui seberapa besar upaya pemerintah dalam hal ini Satpol PP Samarinda dalam mengatur atau menata PKL di wilayah setempat terkhusus di area lokasi pasar jalan sungai Dama. Didapati hasil dari penelitian tersebut bahwa penerapan aturan dan penataan PKL sudah sesuai dengan aturan yang berlaku di antaranya ketersediaan sarana maupun prasarana bagi PKL, penertiban dengan cara sidak pasar yang sebelumnya dilakukan dengan cara sosialisasi ke PKL, serta pembinaan PKL untuk meningkatkan sistem sumber daya manusia. Kendati demikian, masih juga ada beberapa faktor penghambat serta kendala dalam penerapan pengaturan serta penataan PKL tersebut (Tantowi, 2018).
Dari kedua penelitian di atas, tentu persamaan subjek yang diteliti adalah kinerja dari satuan Pol PP untuk membantu Pemerintah dalam hal menegakkan Perda dan ketertiban umum. Hanya saja objek penelitian terdapat perbedaan antara penelitian di atas dengan penelitian yang hendak dilakukan. Penelitian ini akan mengangkat objek teliti yakni keberadaan petugas Pol PP menjaga Pos Pol PP Desa di setiap wilayah desa dan kelurahan se kabupaten Empat Lawang. Juga operasi kerja Pol PP bersumber dari aplikasi Siap Pol PP Desa yang dirancang, dirintis oleh pemerintah Empat Lawang

\section{Metode Penelitian}

Metode penelitian yang digunakan adalah deskriptif kualitatif. Sedangkan objek penelitian dalam penelitian ini berfokus kepada aktifitas komunikasi pemerintah Empat Lawang dalam mengimplementasikan Pol PP Desa di kabupaten Empat Lawang. Selanjutnya data tersebut dianalisis dengan menggunakan teori manajemen SWOT. Dimulai dari huruf S yang bermaksud Strengths artinya kekuatan, kemudian huruf $\mathrm{W}$ yang bermaksud Weakness artinya kelemahan, lalu huruf O yang bermaksud Opportunities yang artinya peluang, dan huruf $\mathrm{T}$ yakni maksudnya Threats artinya ancaman.

\section{Hasil Penelitian dan Pembahasan}

1. Program Pol PP Desa

Program Pol PP Desa merupakan program rintisan kabupaten Empat Lawang diilhami dari buah pikiran Bupati Empat Lawang $\mathrm{H}$ Joncik Muhammad yang menginginkan di Bumi Saling Keruani Sangi Kerawati ini aman, dan nyaman.

Saya mengharapkan dukungan dari berbagai pihak untuk membantu kerja pemerintah Empat Lawang, salah satunya program yang menjadi skala prioritas bagi pemerintah 
Empat Lawang adalah dengan menekan angka kejahatan kriminal di Bumi Saling Keruani Sangi Kerawati yang kita cintai ini.

Perihal itu kerap disampaikannya hampir di setiap pertemuan dan kegiatan. Baik agenda pemerintah melalui dinas, maupun agenda pertemuan dengan masyarakat. Dari hal ini, bupati Empat Lawang H Joncik Muhammad berkehendak komunikasi dengan berbagai elemen baik organisasi perangkat daerah (OPD), masyarakat, aparat kepolisian, alim ulama, dan aktifis lainnya untuk bersama-sama membangun kabupaten Empat Lawang serta menekan angka kejahatan kriminal.

Selanjutnya gagasan dari bupati tersebut, dicerna langsung oleh KaSatpol PP Empat Lawang ketika itu, yakni Candra SH MM (KaSatpol PP Empat Lawang periode 7 Februari 2018-10 Oktober 2019) bertajuk program penanggulangan keamanan di Empat Lawang dengan nama program Pol PP Desa.

Bermula dari sekolah pelatihan kepemimpinan nasional (PKN) tingkat 2 angkatan ke 22 tahun 2019 yang diikutinya selama 6 bulan. Dimana pada sekolah tersebut, salah satu kewajiban akhirnya harus memiliki visi misi proyek perubahan. Sehingga beliau mengilhami amanat tugas dari Bupati Empat Lawang $\mathrm{H}$ Joncik Muhammad terkait persoalan keamanan di Empat Lawang. Tak pelak lagi, dirinya mengangkat proyek perubahan berupa program Pol PP Desa. Ternyata rintisan program ini mendapatkan dukungan dari berbagai pihak. Mulai dari support anggaran pemerintah APBD Empat Lawang diputuskan masuk anggaran induk APBD, dengan alokasi anggaran gaji petugas Pol PP Rp 1.800.000/petugas Pol PP dikalikan sejumlah 147 desa dan 9 kelurahan dan setiap desa ditugaskan sebanyak 2 orang petugas Pol PP. Lalu ditambah dengan Pos Jaga serupa dengan Pos keamanan lingkungan (Poskamling) di masing-masing desa. Kendatipun APBD Empat Lawang masih relatif rendah. Akan tetapi dukungan masyarakat sangat positif, menyambut dengan senang hati berupa penempatan petugas Pol PP tersebut ada yang melebihi 2 orang, bahkan juga ada yang terdapat hingga 5 orang dengan catatan hanya sebatas mendukung penuh dalam program penekanan angka kejahatan di Kabupaten Empat Lawang.

Sementara itu, KaSatpol PP Empat Lawang yang ditugaskan setelah 10 Oktober 2019 hingga sekarang, Suan Amri didampingi Kabid Penegakan Perundang-Undangan Daerah (PPUD) Ridho Oktaviani menerangkan, petugas program Pol PP Desa ini sama halnya dengan petugas anggota Pol PP yang berada di kantor. Hanya saja, petugas Pol PP Desa ini ditugaskan konsentrasi nya lebih banyak keamanan ditingkat desa sesuai dengan penempatan Surat Keputusan (SK) yang ditetapkan. Bahkan pihaknya mengapresiasi kepada masyarakat Empat Lawang secara swadaya untuk membangun Pos Jaga Pol PP Desa. Pun tak sedikit beberapa petugas Pol PP Desa melakukan sharing honor dalam penugasannya. Lantaran bersepakat turut menjaga di Pos Jaga melebihi 2 hingga beberapa orang. Hal itupun tidak menjadi persoalan baginya. Karena misi utama keberadaan Petugas Pol PP Desa membantu pemerintah, aparat kepolisian dalam urusan keamanan di Empat Lawang.

Ridho mengatakan, pihaknya selalu menekankan kepada petugas Pol PP Desa untuk melaksanakan tugasnya harus mengindahkan SOP yang berlaku. Tidak melakukan tindakan yang melebihi batas kewajaran. Dan apabila ada kejadian yang perlu mendapatkan tanggapan cepat, sekiranya koordinasi dengan anggota Polisi terdekat atau melaporkannya kepada atasan. 
Implikasi dari program tersebut ternyata membuahkan hasil. Data dari kepolisian Empat Lawang, tercatat angka kejahatan kriminal yang meresahkan masyarakat banyak seperti begal, pencurian kekerasan di kabupaten Empat Lawang mengalami penurunan. Perbandingan tersebut antara tahun 2018 dengan 2019 sebagaimana diungkapkan Bapak AKBP Eko Budi Haryanto:

Angka kejahatan kriminal seperti begal dan pencurian kekerasan di tahun 2019 mengalami penurunan di bandingkan tahun 2018 .

Hal serupa juga diungkap oleh masyarakat Empat Lawang, Andi Wijaya mengucapkan terima kasih kepada pemerintah Empat Lawang telah menerapkan program Pol PP Desa. Karena program itu sangat efektif dan bisa membuat masyarakat lebih aman dan nyaman.

Ya betul, kita akui kejahatan di Empat Lawang menurun, semoga program ini terus berlanjut.

\section{Aplikasi SIAP Pol PP Desa}

Pol PP Desa ini dilengkapi dengan fasilitas aplikasi sistem yang dapat diunduh langsung di play store bernama SIAP Pol PP Desa. Yang mana aplikasi tersebut berfungsi sebagai barometer kontrol kerja petugas Pol PP di lapangan sebagaimana dijelaskan Bapak Candra:

Aplikasi pertama di Indonesia dalam hal penugasan Pol PP di setiap desa, dan kelurahan. Kemudian operasi dari aplikasi itu terdapat beberapa menu yang tersaji. Salah satunya pelaporan informasi yang dikirim langsung oleh rakyat/netizen, juga bisa petugas Pol PP itu sendiri lalu di proses oleh admin. Kemudian admin yang terdiri dari Bupati, Wakil Bupati, Kapolres, dan KaSatpol PP, meneruskannya ke petugas Pol PP untuk menerima laporan tersebut dan langsung memberikan perintah untuk petugas Pol PP yang ada di lapangan, ataukah menolak dari laporan tersebut bila laporannya hoax dan tidak sesuai fakta di lapangan.

Aplikasi Siap Pol PP Desa mendapatkan tanggapan positif dari Kementerian Dalam Negeri. Bahkan aplikasi tersebut diikut sertakan lomba Nusantara Innovation Summit bertema "Inovasi Untuk Pelosok Negeri dalam Era Revolusi 4.0" yang digelar oleh Institut Pemerintahan Dalam Negeri (IPDN) pada 11-15 Maret 2020, dan hasilnya mendapatkan peringkat terbaik ketiga. Meskipun diakuinya belum begitu maksimal penggunaan aplikasi Siap Pol PP Desa di kabupaten Empat Lawang. Namun pihaknya tengah merencanakan evaluasi konstruktif eksistensi aplikasi Siap Pol PP Desa di kabupaten Empat Lawang.

Bentuk operasi kerja aplikasi SIAP Pol PP Desa bersumber dari elemen serta peran dan tugasnya masing-masing sebagai berikut:

a. Netizen/rakyat, masyarakat

Netizen/rakyat, masyarakat yang hendak berkontribusi dalam program ini sebaiknya install aplikasi Siap Pol PP Desa melalui menu play store di handphone. Kemudian turut memantau kondisi masing-masing desa, dusun, atau lingkungan wilayah kabupaten Empat Lawang. Lalu menyampaikan informasi, laporan adanya kejadian yang berkaitan dengan masalah keamanan, atau sesuai dengan tugas pokok fungsi keberadaan Pol PP

b. Petugas Pol PP Desa

Sama halnya dengan netizen, masyarakat, bahwa petugas Pol PP Desa diwajibkan menginstall aplikasi Siap Pol PP Desa di menu play store masing-masing android. Lalu mereka melaksanakan tugas berjaga Pos Pol PP Desa sesuai dengan wilayah penugasan/pos jaga yang 
dimandatkan dari KaSatpol PP. Kemudian petugas Pol PP lapangan tersebut memberikan informasi, dan laporan segala sesuatu aktifitas yang berkaitan dengan tugas terlebih lagi bila ada kejadian kejahatan. Dan terakhir melaksanakan perintah yang dikeluarkan/ditugaskan dari admin sebagai bentuk pelaksanaan tugasnya.

\section{c. Admin Aplikasi Siap Pol PP Desa}

Admin aplikasi Siap Pol PP Desa terdiri dari Bupati, wakil bupati, KaSatpol PP, dan Kapolres. Tugasnya antara lain memantau setiap perkembangan aplikasi Siap Pol PP Desa setiap hari 24 jam. Lalu memverifikasi setiap informasi, laporan yang masuk ke aplikasi Siap Pol PP Desa. Setelah mengkroscek tentu ada beberapa menu pilihan, yang pertama apabila menerima laporan dari netizen/rakyat, dan atau petugas Pol PP Desa maka segera memberikan perintah/kebijakan tugas bagi petugas Pol PP yang berada di lapangan, ataukah hanya sebatas penerimaan laporan semata. Kemudian apabila menolak laporan dari netizen/rakyat, dan atau petugas Pol PP maka secara otomatis terhapus dari aplikasi laporan tersebut. Lazimnya laporan ditolak admin bisa berupa informasi tersebut hoax, informasi tersebut tidak ada kaitan dengan penugasan Pol PP kabupaten Empat Lawang.

\section{Program KRYD Polres Empat Lawang}

Kepolisian Resort (Polres) Empat Lawang juga memiliki program prioritas sebagai bentuk kerjasama dengan pemerintah dalam rangka untuk menekan angka kejahatan kriminal di Empat Lawang. Program tersebut bertajuk Kegiatan Rutin Yang Ditingkatkan (KRYD). Program ini direalisasikan dengan cara mengerahkan pasukan gabungan yang terdiri dari satuan Reserse Kriminal (Reskrim), Intel, dan Satlantas. Dalam 1 bulannya dibagi menjadi 4 kelompok, yakni kelompok A, B, C, dan D. Bergerak setiap hari libur/malam libur yakni malam Sabtu dan malam Minggu dengan cara mengelilingi kabupaten Empat Lawang, dan menyusuri setiap kecamatan, kelurahan, dan desa yang didapati informasi sebagai daerah rawan dan kerap terjadi kejahatan.

Program ini telah berjalan sejak 4 bulan yang lalu. Selain sebagai perintah program dari Kapolda Sumsel, juga berkaitan dengan upaya pemerintah Empat Lawang untuk menekan angka kejahatan kriminal di Empat Lawang. Kemudian pihaknya juga menugaskan 5 orang pasukan Sabhara untuk melakukan patroli rutin secara bergiliran ke kecamatan, desa, dan kelurahan se kabupaten Empat Lawang. Mereka bergerak baik siang maupun malam hari. Hal ini tergantung dengan informasi bersumber dari masyarakat maupun dari satuan intel. Bahkan ketika berproses di lapangan, tak jarang sering berjumpa dengan petugas Pol PP Desa.

Masyarakat pun diberikan wewenang kontribusi dalam rangka menciptakan keamanan dan kenyamanan kabupaten Empat Lawang. Salah satunya dengan cara melaporkan setiap kejadian kejahatan di Empat Lawang ke Call Center 110, namun dengan catatan laporan tersebut benar adanya dan bukan hoaks. Dan dari laporan tersebut akan ditindaklanjuti cepat oleh aparat kepolisian baik di tingkat polsek, polres, bahkan polda. Karena mereka dilengkapi dengan WhatsApp group (WAG) di Polres Empat Lawang juga di Polda Sumatera Selatan.

Sebagaimana pendahuluan yang telah disampaikan sebelumnya, maka analisis pembahasan pada penelitian ini menggunakan teori manajemen strategi SWOT yakni singkatan dari Strengths (S/kekuatan), Weakness (W/kelemahan), Opportunities (O/peluang), dan Threats (T/ancaman). Selanjutnya telah dilakukan wawancara dan survei di lapangan didapati temuan sebagai berikut: 
1. Lingkungan Internal

\section{a. Strenght/S, Kekuatan}

Program Pol PP Desa memiliki kekuatan diantaranya PP No 16 tahun 2018 tentang Satpol PP, SOP, dan Peraturan Daerah (perda) No 9 tahun 2016 Pembentukan dan Susunan Perangkat Daerah Kabupaten Empat Lawang. Kemudian adanya Pos Pol PP Desa di setiap desa dan kelurahan. Lalu anggaran APBD Empat Lawang berupa honor petugas Pol PP sejak tahun 2019. Dan yang pastinya dilengkapi dengan aplikasi Siap Pol PP Desa yang bisa diinstall melalui handphone setingkat android melalui menu play store.

b. Weakness/W, Kelemahan

Setelah dianalisis, program Pol PP Desa ini terdapat beberapa kekurangan. Setidaknya kekurangan ini sebagai bahan evaluasi bagi pemerintah Empat Lawang untuk melakukan perbaikan konstrktif ke depan. Kekurangan tersebut diantaranya kurangnya pemahaman petugas Pol PP di lapangan dalam penggunaan aplikasi Siap Pol PP Desa. Dan hal ini berimplikasi dengan minimnya, jarang/tidak rutin memberikan laporan kondisi di lapangan. Kondisi tersebut terlihat dari aplikasi Siap Pol PP Desa yang kerap sepi dalam pelaporan, penyampaian informasi. Kemudian minimnya pengawalan, kontrol laporan dari admin aplikasi Siap Pol PP Desa sebagai bentuk lanjutan proses penerimaan laporan dan selanjutnya memberikan amanat, perintah, ataukah menolak laporan tersebut.

2. Lingkungan Eksternal

a. Opportunity/O, Peluang

Program Pol PP Desa berikut aplikasi Siap Pol PP Desa ini memiliki peluang di antaranya masyarakat berkesempatan turut membantu memberikan laporan, informasi kejadian di masing-masing desa. Kemudian Polres Empat Lawang menugaskan beberapa anggota Sabhara, dan anggota gabunganpatroli ke desa-desa, kelurahan, dan kecamatan se kabupaten Empat Lawang secara bergiliran dalam tajuk program Kegiatan Rutin Yang Ditingkatkan (KRYD), sekaligus mengunjungi Pos Pol PP Desa di lapangan.

b. Threats/T, Ancaman

Kendatipun program rintisan Pol PP Desa di Empat Lawang ini telah terbukti mengurangi angka kejahatan kriminal. Namun setidaknya menjadikan ancaman ini sebagai bahan dasar untuk ditindaklanjuti oleh pemerintah Empat Lawang dalam rangka memaksimalkan program Pol PP Desa di masa mendatang. Ancaman tersebut antara lain ketersediaan signal handphone yang tak merata di setiap desa kabupaten Empat Lawang, mengakibatkan tak semua petugas Pol PP Desa di lapangan yang berperan aktif memberikan laporan, informasi. Kemudian adanya laporan masyarakat/ netizen tak bertanggung jawab alias hoax dalam memberikan informasi. Hal ini tertampak pada aplikasi Siap Pol PP Desa yang dari daerah jauh (luar kabupaten Empat Lawang) dapat juga mengirimkan laporan. Sehingga berpengaruh dengan proses penerimaan laporan oleh admin apabila tidak diteliti.

\section{Empat Alternatif Analisis SWOT}

a. Strategi SO

1) Memberikan reward/penghargaan kepada masyarakat, netizen/rakyat yang kerap menyampaikan informasi ke aplikasi android Siap Pol PP Desa

2) Mengkorelasikan program Pol PP Desa dan KRYD dari Polres Empat 
Lawang terhadap menu di aplikasi android Siap Pol PP Desa

3) Memberikan reward/penghargaan kepada anggota Sabhara/anggota gabungan Polres Empat Lawang yang berperan aktif mengunjungi Pos Jaga Pol PP Desa dengan bukti otentik laporan di aplikasi Siap Pol PP Desa

b. Strategi WO

1) Kombinasikan Petugas Pol PP Desa untuk pemahaman penggunaan aplikasi Siap Pol PP Desa dengan masyarakat/netizen, rakyat. Terlebih lagi netizen itu merupakan warga sekitar dan dikenal oleh Petugas Pol PP Desa tersebut.

2) Bertukar pikiran, koordinasi petugas Pol PP Desa dengan petugas gabungan, anggota Sabhara Polres Empat Lawang yang berpatroli dan mengunjungi Pos Jaga Pol PP Desa.

c. Strategi ST

1) Dalam hal persoalan signal handphone, Bupati Empat Lawang $\mathrm{H}$ Joncik Muhammad akan mengambil langkah pengadaan alat Handy Talky (HT) sebagai bentuk keseriusan pemerintah dalam hal program penekanan angka kejahatan kriminal di Empat Lawang. Selanjutnya HT tersebut diperuntukkan pos-pos jaga yang signal rendah. Selain itu akan berkoordinasi dengan pengusahapengusaha tower dalam rangka maintenance tower yang ada, dan penambahan armada tower yang belum terjangkau di wilayah Empat Lawang.

2) Mewajibkan seluruh petugas Pol PP Desa untuk kepemilikan handphone android yang dapat menampung aplikasi Siap Pol PP Desa

3) Memerintahkan kepada seluruh Petugas Pol PP Desa untuk belajar penggunaan handphone android sekaligus operasi aplikasi Siap Pol PP Desa

4) Menolak laporan hoax dari netizen/ masyarakat yang tidak bertanggung jawab dalam menyampaikan informasi. Atau apabila perlu dilakukan blacklist terhadap netizen tersebut. Dan sebaiknya menu blacklist pada aplikasi Siap Pol PP Desa diadakan sebagai upaya filterisasi dari laporan hoax.

d. Strategi WT

1) Mewajibkan kepada setiap petugas Pol PP Desa yang berada di Pos Jaga untuk memberikan laporan setiap hari minimal 1 kali.

2) Membuat Surat Keputusan (SK) petugas admin yang ditempatkan kantor Satpol PP Empat Lawang. Berfungsi sebagai pengawasan, kontrol laporan dari petugas Pol PP Desa yang mengirimkan laporan ke aplikasi Siap Pol PP Desa dengan penuh kehati-hatian dan teliti. Dengan catatan untuk langkah amanat, perintah wajib koordinasi dengan KaSatpol PP sebagai koordinator dan apabila perlu 
dengan tanggapan darurat yang memerlukan kebijakan dan tindakan dari kepala daerah, KaSatpol PP mengkoordinasikan dengan Bupati dan Wakil Bupati.

\section{Kesimpulan}

Berdasarkan hasil penelitian maka dapat diketahui bahwa strategi komunikasi pemerintah memasuki tahun kedua pengabdian sebagai Bupati Empat Lawang $\mathrm{H}$ Joncik Muhammad dan pasangannya Wakil Bupati H Yulius Maulana dalam mengimplementasikan program Pol PP Desa di Kabupaten Empat Lawang sudah sangat efektif. Selain memiliki anggaran tersendiri untuk honor petugas Pol PP, pendirian Pos Jaga Pol PP Desa dilakukan secara mandiri dan swadaya masyarakat, serta adanya aplikasi SIAP Pol PP Desa. Selain itu juga didukung penuh oleh Polres Empat Lawang berupa program bertajuk Kegiatan Rutin Yang Ditingkatkan (KRYD). Hal ini berimplikasi dengan angka kejahatan kriminal di Bumi Saling Keruani Sangi Kerawati yang didata oleh Polres Empat Lawang mengalami penurunan. Meskipun secara akumulatif masih ada kejahatan di Empat Lawang, akan tetapi kejahatan yang berdampak secara langsung keresahan masyarakat banyak seperti begal, pencurian kekerasan mengalami penurunan dan dapat dirasakan langsung oleh masyarakat Empat Lawang. Kendati ada beberapa kelemahan dalam operasi aplikasi Siap Pol PP Desa, mulai dari minimnya laporan dari netizen maupun petugas Pol PP yang ada di lapangan, termasuk pula gagap teknologi beberapa petugas Pol PP di lapangan terkait penggunaan handphone android, bahkan persoalan signal handphone disetiap Pos Jaga, tentu ada perbaikan dan strategi dari pemerintah untuk mengantisipasi hal tersebut di masa mendatang.

\section{Daftar Pustaka}

Badan Pusat Statistik Kabupaten Empat Lawang. 2018. Kabupaten Empat Lawang Dalam Angka Empat Lawang Regency in Figures 2018. Jakarta: Alief Media Grafika.

Sriwijaya Post. "Berita Empatlawang: Jamin Keamanan Tiap Desa, Pemkab Rekrut Pol PP Desa Awal Tahun.” Diakses 31 Maret 2020. https://palembang.tribunnews.com/2018/10/2 8/berita-empatlawang-jamin-keamanan-tiapdesa-pemkab-rekrut-pol-pp-desa-awal-tahun.

Bupati Empat Lawang H Joncik Muhammad. Program Pol PP Desa, 11 Maret 2020.

Candra SH MM (KaSatpol PP Empat Lawang Periode 2018-2019). Program Pol PP Desa 1, 12 Maret 2020.

Edi, Suryadi, dan Strategi Komunikasi. "Sebuah Analisis Teori dan Praktis di Era Global." Bandung: PT Remaja Rosdakarya, 2018.

Finer, Samuel Edward. Comparative government. Penguin (Non-Classics), 1974.

Hasan, Erliana. "Komunikasi Pemerintahan," 2014.

Humphrey, Albert. "SWOT analysis for management consulting." SRI alumni Newsletter 1 (2005): 7-8.

Jufita, puspa sari. "Strategi Satuan Polisi Pamong Praja (SATPOL PP) Dalam Penertiban Pedagang Kaki Lima Kota Tanjungpinang (Studi Pada Wilayah Pasar Kelurahan Tanjungpinang Kota).” Strategi Satuan Polisi Pamong Praja (SATPOL PP) Dalam Penertiban Pedagang Kaki Lima Kota Tanjungpinang (Studi Pada Wilayah Pasar Kelurahan Tanjungpinang Kota), 21 Agustus 2018. http://fisip.umrah.ac.id/.

Lawang, Rakyat Empat. "Pelantikan Bupati dan Wakil Bupati Berlangsung Khidmat." Diakses $31 \quad$ Maret 2020. http://rakyatempatlawang.com/pelantikanbupati-dan-wakil-bupati-berlangsungkhidmat/.

Moleong, Lexy J. "Penelitian kualitatif." Jakarta: Rineka Cipta, 2009.

Onong, Uchjana Effendy. "Ilmu komunikasi teori dan praktek." Bandung: PT Remaja Rosdakarya, 1984.

"Peraturan Pemerintah RI No 6 tahun 2010 TENTANG SATUAN POLISI PAMONG PRAJA.pdf," t.t.

"Peraturan Pemerintah RI Nomor 16-Tahun 2018 
Tentang SATUAN POLISI PAMONG PRAJA.pdf," t.t.

"PERDA NOMOR 9 TAHUN 2016 TENTANG PEMBENTUKAN DAN SUSUNAN PERANGKAT DAERAH KABUPATEN EMPAT LAWANG.pdf," t.t.

"PERMENDAGRI NOMOR 54 tahun 2011 TETANG STANDAR OPERASIONAL PROSEDUR SATUAN POLISI PAMONG PRAJA.pdf," t.t.

"Sejarah - Empat Lawang." Diakses 31 Maret 2020.

https://empatlawangkab.go.id/v2/sejarah/.

Suryadi, Edi. "Strategi Komunikasi." PT Remaja Rosdakarya, Bandung, 2018.

Tantowi, Ibnu. "IMPLEMENTASI PENATAAN PEDAGANG KAK LIMA (PKL) OLEH SATUAN POLISI PAMONG PRAJA KOTA SAMARINDA." ADMINISTRASI PUBLIK 2, no. 1 (17 September 2018): 1-5.

"UU RI 22 TAHUN 1999 TENTANG PEMERINTAHAN DAERAH.pdf," t.t.

"UU RI NOMOR 1 TAHUN 2007 TENTANG PEMBENTUKAN KABUPATEN EMPAT LAWANG DI PROVINSI SUMATERA SELATAN.pdf," t.t.

"UU RI NOMOR 32 TAHUN 2004 TENTANG PEMERINTAHAN DAERAH.pdf," t.t. 